\title{
Evaluasi Pemanfaatan Aplikasi Enterprise Resource (ERP) Dengan Framework Cobit 4.1
}

\author{
Erma Zulhijjah $^{1}$, Nur Lutfiyana ${ }^{2}$
}

\begin{abstract}
To facilitate data processing, PT. Metrox Mekanika implements an Enterprise Resource Planning (ERP) application system to improve user performance. With the development of information systems in the business world, every employee of the company needs to adapt and learn, so that the application system can be well received. The existence of an evaluation of the application system is expected to help users of the application system in using the application system. This research is a form of evaluation of the ERP Enterprise Resource Planning (ERP) application system. The research method used in this study is a survey method, namely by taking or collecting data through a questionnaire. Some of these problems can be classified as processes within the Plan and Organize and Monitor and Evaluate domains in the COBIT 4.1 framework. COBIT 4.1 is used to determine the level of IT maturity and also provide recommendations from the evaluation activities carried out. The evaluation results show that in the $P O$ domain the average maturity level is 4.03 or reaches level 4 (Managed and Measureable), while in the ME domain the average maturity level is 4.03 or reaches level 4 (Managed and Measureable). Recommendations are given with the aim that PT. Metrox Mekanika can increase the value of IT maturity level, so that existing IT governance forms can be improved.
\end{abstract}

Intisari- Untuk memudahkan pengolahan data, PT. Metrox Mekanika menerapkan system aplikasi Enterprise Resource Planning (ERP) untuk meningkatkan kinerja user/pengguna. Dengan berkembangnya sistem informasi di dunia perbisnisan, maka setiap karyawan perusahaan perlu beradaptasi dan belajar, agar sistem aplikasi dapat diterima dengan baik. Adanya evaluasi sistem aplikasi di harapkan dapat membantu pemakai sistem aplikasi dalam menggunakan sistem aplikasi tersebut. Penelitian ini merupakan suatu bentuk evaluasi terhadap sistem aplikasi Enterprise Resource Planning (ERP). Metode penelitian yang digunakan dalam penelitian ini adalah metode survey yaitu dengan mengambil atau mengumpulkan data melalui kuesioner. Beberapa permasalahan tersebut dapat digolongkan pada proses di dalam domain Plan and Organise dan Monitor and Evaluate pada kerangka kerja COBIT 4.1. COBIT 4.1 digunakan untuk mengetahui tingkat kematangan TI dan juga memberikan rekomendasi dari kegiatan evaluasi yang dilakukan. Hasil evaluasi menunjukkan, pada domain $P O$ nilai rata-rata tingkat kematangannya sebesar 4.03 atau mencapai level 4 (Managed and Measureable, sedangkan pada domain ME nilai rata-rata tingkat kematangannya sebesar 4,03 atau mencapai level 4 (Managed and Measureable). Rekomendasi diberikan dengan tujuan agar PT. Metrox Mekanika dapat meningkatkan nilai tingkat kematangan TI, sehingga bentuk tata kelola TI yang ada dapat diperbaiki.

Kata Kunci- Evaluasi,Cobit, Tingkat Kematangan, ERP.

\footnotetext{
1,2 Jurusan Sistem Informasi, Universitas Nusa Mandiri, Jln. Kramat Raya No. 18 Jakarta Pusat 10450 INDONESIA tlp: 08158544 2191; 021-31908575 e-mail: 11200262@nusamandiri.ac.id, nur.lutfiyana@yahoo.com
}

\section{PENDAHULUAN}

PT. Metrox Mekanika adalah perusahaan ritel yang menghadirkan kebutuhan gaya hidup terbaik bagi konsumen modern sejak tahun 2004. Dalam pelayanannya PT. Metrox Mekanika sudah menggunakan sistem informasi. Dengan teknologi sistem informasi yang semakin canggih dan berkembang, maka dapat memudahkan sistem kerja dan mempercepat proses kerja karyawan. Hal ini yang memicu PT. Metrox Mekanika harus mengikuti perkembangan yang ada.

Pengembangan sistem informasi di era sekarang banyak sekali kita rasakan manfaatnya, karena kecanggihannya dalam menghitung khususnya untuk memproses data yang sangat banyak dan rumit. Manfaat sistem informasi sudah tidak kita ragukan lagi karena dengan adanya sistem informasi akan membantu perusahaan untuk mempermudah pengelolaan data serta menyajikan sebuah hasil yang berkualitas dan berguna bagi perusahaan. Maka setiap perusahaan memerlukan sistem yang bisa mengatur semua proses yang terjadi, mulai dari proses mengumpulkan, memasukan, mengelola dan menyimpan data- data. Sistem informasi merupakan suatu gabungan dari user, hardware, software, jaringan komunikasi dan sumber daya informasi yang megumpulkan, mengubah, menyebarkan informasi dan sebuah organisasi[1].

Maka dari itulah, sistem informasi sangat dibutuhkan bagi keberlangsungan suatu perusahaan begitu juga dengan kemajuan teknologi dapat mendukung pengolahan informasi menjadi alat pemicu persaingan dunia bisnis dan ekonomi yang semakin baik. PT. Metrox Mekanika, sebagai salah satu perusahaan ritel yang memiliki sebuah sistem informasi yang disebut ERP (Enterprise Resource Planning) atau dalam bahasa Indonesia sering disebut dengan Perencanaan Sumber Daya Perusahaan adalah struktur sistem informasi yang dapat mengintegrasikan fungsi pemasaran (marketing),fungsi produksi, fungsi logistik, fungsi keuangan/finance, fungsi sumber daya dan fungsi lainnya. ERP (Enterprise Resource Planning) telah berkembang sebagai alat integrasi yang memiliki tujuan untuk mengintegrasikan semua aplikasi perusahaan ke pusat penyimpanan data sehingga dapat dengan mudah di akses oleh semua bagian yang membutuhkan.

Setelah sistem Enterprise Resource Planning (ERP) berjalan, bukanlah berarti telah selesai implementasi dilakukan, bahkan tantangan baru dimulai saat setelah implementasi ERP maka dari itu perlunya suatu analisa penerapan ERP (Enterprise Resource Planning) dengan suatu metode yang dapat memberikan rekomendasi dalam penerapan ERP (Enterprise Resource Planning). Contoh kerangka kerja yang telah mendapat pengakuan luas oleh masyarakat internasional adalah COBIT (Control Objective for Information and Related Technology). Salah satu penilaian dalam manajemen Sistem Informasi yang ditetapkan oleh COBIT adalah pengukuran maturity level atau tingkat 
kematangan. Dengan pengukuran tersebut, akan diketahui sejauh mana tingkatan pengelolaan Sistem Informasi tersebut berada, yang aka memungkinkan pihak manajemen perusahaan mengetahui apa saja kekurangan dan ke arah mana seharusnya Sistem Informasi dikembangkan dan dikelola. Sehingga dalam mengevalusai tingkat kematangan penerapan Enterprise Resource Planning (ERP) pada PT. Metrox Mekanika. Maka pembahasan dalam penelitian mefokuskan pada pengawasan dan evaluasi kontrol serta layanan, yang bertujuan untuk mengevaluasi tingkat kematangan layanan TI pada PT. Metrox Mekanika yang diharapkan bisa membawa perubahan yang positif dan sesuai dengan tujuan dan perencanaannya.

Penulis melakukan penelitian secara langsung di PT. Metrox Mekanika, Jakarta. Penulis mengadakan wawancara dengan karyawan PT. Metrox Mekanika. Dari hasil wawancara dan observasi langsung, tidak sedikit pula keluhankeluhan yang timbul dari karyawan terhadap kinerja ERP (Enterprise Resource Planning), seperti proses input data yang terkadang pergerakannya lamban apabila banyak pengguna yang sedang menggunakan apliaksi ERP (Enterprise Resource Planning) pada saat-saat tertentu, misal pada saat akhir bulanan, Beberapa akses yang biasanya bisa dibuka ketika server down langsung tidak bisa dibuka sehingga diperlukan pelaporan ke IT untuk minta dibukakan aksesnya kembali. Dengan adanya kendala-kendala yang dihadapi tentunya akan berperngaruh terhadap kinerja karyawan.

Dari latar belakang diatas, maka penulis ingin mengetahui tingkat kematangan layanan TI pada PT. Metrox Mekanika dengan adanya pemanfaatan teknologi informasi di aplikasi Enterprise Resource Planning (ERP) penulis berharap dapat mengetahui sejauh mana aplikasi ini diterapkan dan apa saja kendala atau kekurangan yang ada pada aplikasi tersebut agar segera bisa ditemukan solusinya dan penggunakaan aplikasi ini dapat digunakan dengan maksimal dalam penggunaannya.

\section{TINJAUAN PUSTAKA}

\subsection{Pengertian Sistem}

Sistem adalah sekumpulan unsur atau elemen yang saling mempengaruhi dalam melakukan kegiatan bersama untuk mencapai tujuan [2]. Berasal dari Bahasa Yunani ialah "systema" yaitu himpunan bagian atau komponen yang saling berhubungan secara teratur dan merupakan suatu keseluruhan. Namun bisa juga diartikan sekelompok elemen yang independen, namun saling terkait sebagai satu kesatuan [3].

\subsection{Pengertian Teknologi}

Teknologi adalah pengembangan dan aplikasi dari alat, mesin, material dan proses yang menolong manusia menyelesaikan masalahnya. Informasi adalah hasil pemrosesan, manipulasi dan pengorganisasian/penataan dari sekelompok data yang mempunyai nilai pengetahuan (knowledge) bagi penggunanya[4].

\subsection{Pengertian Informasi}

Menurut Sutanta informasi merupakan sebuah hasil dari pengolahan data sehingga menjadi bentuk yang penting bagi si penerima informasi. Dengan adanya informasi, dapat dijadikan sebagai dasar untuk pengambilan keputusan oleh si penerima informasi, yang mana dapat dirasakan akibatnya baik secara langsung maupun tidak langsung[5].

\subsection{Pengertian Teknologi Informasi}

Teknologi informasi merupakan salah satu komponen dalam sebuah perusahaan. Komponen lainnya antara lain proses dan prosedur, struktur organisasi, sumberdaya manusia, produk, pelanggan, supplier, rekanan dan lain sebagainya. Menurut pendapat lain secara teori, sistem informasi yang baik belum tentu harus memiliki komponen teknologi informasi ( perusahaan pengrajin dengan omset miliaran), sementara disisi lain computer memegang peranan sangat penting dalam penciptakan produk (perusahaan manufaktur jepang yang mempekerjakan robot utk semua proses perakitan). Jadi keandalan suatu sistem informasi dalam perusahaan atau organisasi terletak pada keterkaitan antara komponen-komponen yang ada, sehingga dapat dialirkan atau dihasilkan suatu informasi ya gn berguna, akurat, terpecaya, relevan detail, cepat dan sebainya untuk organisasi yang bersangkutan[6].

\subsection{Perangkat-perangkat Teknologi Informasi}

Dalam menggunakan TI dibutuhkan perlengkapan/ perangkat yang bisa digunakan untuk mendapatkan sebuah informasi, berikut Perangkat-perangkat TI menurut Jamal M.A[7] :

a. Komputer

Komputer merupakan perangkat keras dan perangkat lunak yang digunakan untuk memudahkan manusia dalam mengolah sebuah data menjadi informasi serta menyimpan untuk ditampilkan dilain waktu. Komputer menghasilakan sebuah informasi berupa tulisan, suara, gambar, vidio serta animasi.

\section{b. Laptop/Notebook}

Laptop/Notebook merupakan perangkat yang kegunaannya sama dengan komputer, akan tetapi bentuknya lebih kecil, praktis dan dapat dibawa kemanapun.

c. Desk book

Deskbook merupan perangkat semacam komputer dan bentuknya jauh lebih simple, yaitu CPU menyatu dengan monitor sehingga dapat diletakkan di manapun tanpa memakan banyak tempat.

d. Flash disk, memory card,

Media penyimpanan data yang dapat menyimpan data dalam jumlah besar.

\subsection{Peranan Teknologi Informasi}

Menurut Dewi, Pendorong utama globalisasi dalam bermacam bidang merupakan kemajuan pesat pada teknologi informasi. karena adanya kemajuan teknologi ini hingga prasarana yang menjadikan globalisasi disegala bidang 
ekonomi, informasi serta sebagainya bisa dibentuk. Kemajuan ini pelaksanaannya sangat pesat, sehingga produk yang dihasilkan dapat berputar dengan cepat,contohnya pada sebuah komputer yang nyaris tiap tahun timbul dengan kemampuan yang semakin canggih. Teknologi Informasi menjalankan peranan di sebagian besar aspek bisnis industri, dari pengembangan produk baru hingga sokongan penjualan serta jasa, dari penyedia informasi pasar hingga informasi untuk analisis keputusan. Untuk suatu industri global, keahlian untuk mendapatkan informasi dari bermacam sistem serta dapat diakses luas oleh para manajer serta karyawan ialah perihal yang sangat berarti[8].

\subsection{Pengertian ERP (Enterprise Resource Planning)}

Enterprise Resource Planning Systems (ERP) adalah Sistem berbasis komputer yang memungkinkan manajemen perusahaan melakukan konsolidasi.

Secara umum ERP (Enterprise Resource Planning) memiliki tiga modul utama yang biasanya dimiliki oleh perusahaan, yakni[9]:

1. Operasi

Modul Operasi umumnya menangani siklus fungsional penting dalam ERP seperti Dasbor, antarmuka online, email, Manufaktur, pengangkutan, pembuatan, periklanan, dan lainlain.

2. Finansial dan Akuntansi

Modul uang dan pembukuan mengelola uang dan pembukuan bagian dari organisasi yang berhubungan dengan keuangan. Misalnya, mengurus cicilan kewajiban, tagihan, kredit, membuat laporan keuangan hingga membuat rencana keuangan organisasi.

3. Sumber Daya Manusia

Modul HR menangani segmen Human Resource Management (HRM). Misalnya, membuat rencana kerja, merekrut perwakilan, menghitung tingkat gaji dan penghargaan, dan lain-lain.

Ketiga modul dasar ini tidak perlu berada dalam satu kerangka kerja ERP, namun harus dalam satu kumpulan data terpadu. Ini akan bekerja dengan pemanfaatan satu informasi yang disatukan. Dalam pelaksanaannya, ketiga modul prinsip tersebut diisolasi menjadi 5 macam kerangka data yang telah dikoordinasikan ke dalam kerangka ERP, khususnya: Manajemen Sumber Daya Manusia (SDM), Manajemen Sumber Daya Keuangan (FRM), Manajemen Rantai Pasokan (SCM), Manufaktur Perencanaan Sumber Daya (MRP), Manajemen Hubungan Pelanggan (CRM).

\subsection{Pengertian Framework}

Untuk meningkatkan aplikasi berbasis desktop ataupun website diperlukan kerangka kerja yang disebut framework [10]. Framework berupa software yang didalamnya terdapat landasan dan kerangka dasar untuk keperluan pengembangan berbagai aplikasi perangkat luna.

Beberapa manfaat dari menggunakan framework [11], yaitu : a. Terjaminnya keamanan kode pada aplikasi yang dibuat.
Fitur library yang menyediakan banyak fungsi, membuat proses coding lebih cepat, menghemat waktu yang tentunya akan mengurangi biaya.

b. Standarisasi kode membuat kolaborasi mudah dilakukan dan pengujian lebih mudah dilakukan.

c. Dokumentasi program lebih terstruktur dan rapi.

Menurut penjelasan di atas dapat disimpulkan bahwa framework adalah kerangka kerja berbentuk software untuk mengembangkan aplikasi berbasis desktop maupun website.

\subsection{Pengertian COBIT}

Cobit ialah kerangka kerja yang sediakan pemecahan untuk tata kelola teknologi informasi lewat domain, proses, tujuan, aktivitas, model kematangan serta struktur yang logis dan tertata

Cobit merupakan salah satu metodelogi yang membagikan kerangka bawah dalam menghasilkan suatu teknologi data yang cocok dengan kebutuhan organisasi dengan senantiasa mencermati faktor- faktor lain yang pengaruhi.

I Putu Agus Swastika dan I Gusti Lanang Agung R $\mathrm{P}$ Cobit merupakan satu metodelogi dalam memberikan kerangka dasar dalam menghasilkan suatu teknologi informasi yang cocok dengan kebutuhan organisasi dengan senantiasa mencermati faktor- faktor lain yang mempengaruh[12]

Menurut Wardani \& Puspitasari dalam F Fenny \& Andry, Fungsi dari Cobit antara lain :

a. Menambah pendekatan/ program audit

b. Menunjang audit kerja dengan arahan audit secara rinci

c. Membagikan petunjuk buat IT governance

d. Selaku menilaian benchmark buat kendali sistem data/ teknologi informasi tingkatkan kontrol system selaku standarisasi pendekatan/ program audit

\subsection{Domain Cobit 4.1}

Terdapat 4 domain pada Cobit 4.1 antara lain yaitu domain Plan and Organise (PO) yang menggunakan alat pendukung mulai dari perencanaan seperti sistem informasi dan sebagainya untuk meningkatkan layanan. Acquire and Implement (AI) merupakan domain yang berisi proses-proses implementasi dari perencanaan yang telah ditetapkan. Deliver and Support (DS) domain cobit yang membahas tentang proses layanan kepada pengguna sistem agar mendapatkan hasil yang maksimal, serta monitor and evaluate (ME) domain yang membahas masalah proses monitoring serta evaluasi terhadap perencanaan yang dilakukan, implementas terhadap layanan yang dibuat dan proses penyampaian layanan kepada pengguna[13].

COBIT mendefinisikan aktivitas TI dalam model proses generik dalam empat domain. Antara lain Merencanakan dan Mengatur, Memperoleh dan Mengimplementasikan, Memberikan dan Mendukung, dan Memantau dan Mengevaluasi. Domain dipetakan ke area tanggung jawab tradisional TI dari merencanakan, membangun, menjalankan, dan memantau[14]

Untuk mengatur TI secara efektif, penting untuk menghargai aktivitas dan risiko dalam TI yang perlu dikelola. 
Mereka biasanya dipesan menjadi domain tanggung jawab untuk merencanakan, membangun, menjalankan, dan memantau. Dalam Kerangka kerja COBIT, domain-domain ini, seperti yang ditunjukkan pada gambar 1, disebut:

1. Plan and Organize (PO)-Memberikan arahan untuk penyampaian solusi (AI) dan penyampaian layanan (DS)

2. Acquire and Implement (AI)-Menyediakan solusi dan melewati mereka untuk diubah menjadi layanan

3. Deliver and Support (DS)-Menerima solusi dan membuatnya dapat digunakan untuk pengguna akhir

4. Monitor and Evaluate (ME) - Memantau semua proses untuk memastikan bahwa arah yang disediakan diikuti

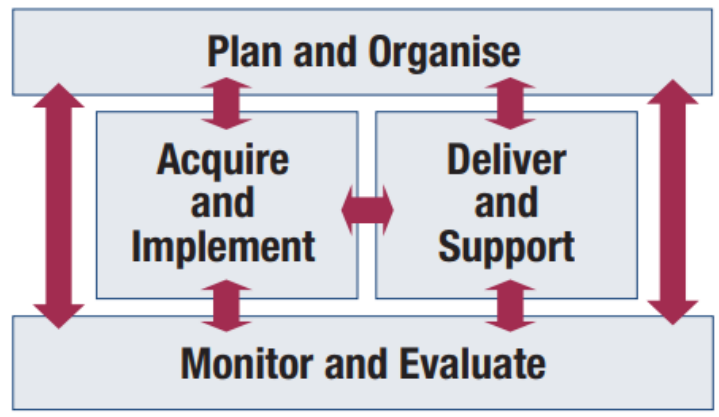

Gambar II.1 , Domain Cobit yang selalu terikat

1. Plan and Organise (PO), domain ini meliputi pada perencanaan dan penyelarasan Teknologi Informasi (TI) dengan strategi perusahaan, termasuk didalamnya adalah strategi, taktik, dan indentifikasi bagaimana TI dapat memberikan peran maksimal terhadap pencapaian tujuan bisnis organisasi sehingga tercipta sebuah organisasi yang baik dengan infrastruktur teknologi yang baik pula.

Tabel II.1 Domain Plan and Organise COBIT 4.1

\begin{tabular}{|l|l|}
\hline \multicolumn{2}{|c|}{ Plan and Organise } \\
\hline PO1 & Define a Strategic IT Plan \\
\hline PO2 & Define the information architecture \\
\hline PO3 & Determine technological direction \\
\hline PO4 & $\begin{array}{l}\text { Define the IT processes., organisation, and } \\
\text { relationships }\end{array}$ \\
\hline PO5 & Manage the IT investment \\
\hline PO6 & Communicate management aims and direction \\
\hline PO7 & Manage IT human resources \\
\hline PO8 & Manage quality \\
\hline PO9 & Assess and manage IT risk \\
\hline PO10 & Manage project \\
\hline PO11 & Manage Quality \\
\hline
\end{tabular}

2. Acquire and Implement (AI), domain ini mengatur pada kegiatan yang berkaitan dengan implementasi solusi teknologi informasi (IT) dan integrasinya dengan proses bisnis didalam organisasinya untuk mewujudkan strategi TI, dan juga meliputi perubahan-perubahan dan pemeliharaan yang dibutuhkan sistem yang berjalan untuk memastikan life cycle system (daur hidup sistem) tetap terjaga.

Tabel II.2 Domain Acquire and Implement (AI)

\begin{tabular}{|l|l|}
\hline \multicolumn{2}{|l|}{ Acquire and Implement } \\
\hline AII & Identify automated solutions \\
\hline AI2 & Acquire and maintain application software \\
\hline AI3 & Acquire and maintain technology infrastructure \\
\hline AI4 & Enable operation and use \\
\hline AI5 & Procure IT resources \\
\hline AI6 & Manage changes \\
\hline AI7 & Install and accredit solutions and changes \\
\hline
\end{tabular}

3.Delivery and Support (DS), terdiri atas proses pemenuhan layanan teknologi informasi (TI) dan keamanan system serta keberlanjutan dari layanan, training (pelatihan) dan Pendidikan untuk pengguna, serta pemenuhan proses data yang sedang berjalan.

Tabel II.3 Domain Delivery and Support (DS)

\begin{tabular}{|l|l|}
\hline \multicolumn{2}{|l|}{ Delivery and Support } \\
\hline DS1 & Define and manage service levels \\
\hline DS2 & Manage third-party service \\
\hline DS3 & Manage performance and capacity \\
\hline DS4 & Ensure continuous service \\
\hline DS5 & Ensure systems security \\
\hline DS6 & Identify and allocate costs \\
\hline DS7 & Educate and train users \\
\hline DS8 & Manage service desk and incidents \\
\hline DS9 & Manage the configuration \\
\hline DS10 & Manage problems \\
\hline DS11 & Manage data \\
\hline DS12 & Manage the physical environment \\
\hline DS13 & Manage operations \\
\hline
\end{tabular}

4.Monitor and Evaluate (ME), fokus pada masalah-masalah pengendalian yang menyeluruh yang diterapkan pada organisasi, pemeriksaan internal dan eksternal serta assurance (jaminan) dari independent dari proses-proses pemeriksaan yang telah dilakukan

Tabel II.4 Domain Monitor and Evaluate (ME)

\begin{tabular}{|l|l|}
\hline \multicolumn{2}{|l|}{ Monitor and Evaluate } \\
\hline ME1 & Monitor and evaluate IT Performance \\
\hline ME2 & Monitor and evaluate internal control \\
\hline$M E 3$ & Ensure compliance external requirements \\
\hline$M E 4$ & Provide IT governance \\
\hline
\end{tabular}




\section{IDENTIFIKASI MASALAH}

Dari riset di PT. Metrox Mekanika tersebut, peneliti merumuskan permasalahan sebagai berikut:

Sistem ERP (Enterprise Resource Planning) sering slow response atau error atau lemot saat closing bulanan karena banyaknya user yang memakai secara bersamaan dan Beberapa akses yang biasa nya bisa dibuka ketika server down langsung tidak bisa dibuka sehingga diperlukan pelaporan ke IT untuk meminta dibukakan akses nya kembali. Belum adanya pengukuran seberapa mudah dan sulitnya dalam mengoperasikan ERP (Enterprise Resource Planning). Belum adanya Evaluasi tingkat kematangan penerapan ERP (Enterprise Resource Planning) pada PT. Metrox Metanika

\section{METODE PENELITIAN}

Metode penelitian yang digunakan pada penelitian ini yaitu metode kualitatif. "Hasil penelitian kualitatif lebih menekankan makna dari pada generalisasi[15]. Oleh karena itu, metode kualitatif digunakan karena metode kualitatif dapat dengan mudah dipahami dan dapat mengevaluasi system serta makna dari system bagi pengguna.

Pada penelitian ini dilakukan 7 tahapan. 7 tahapan penelitian yang dilakukan dapat digambarkan sebagai berikut:

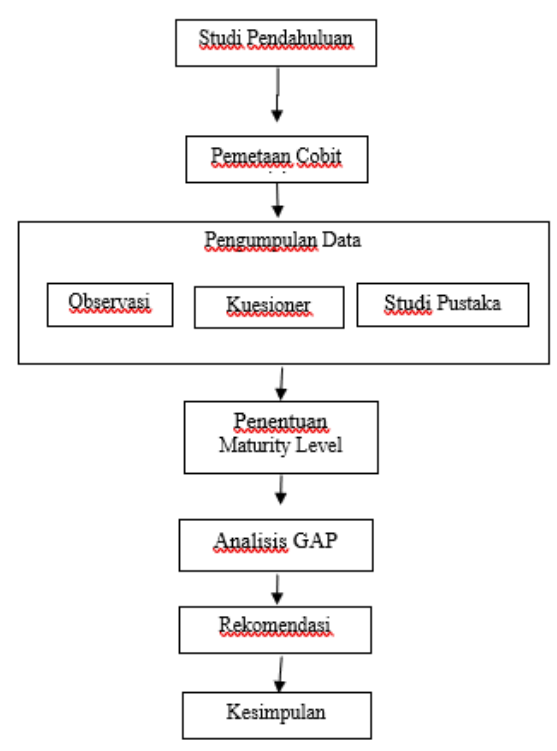

Gambar III. 1 Tahapan Penelitian

a. Studi Pendahuluan

Penelitian ini dilakukan dengan cara mencari dan mengumpulkan data, sumber informasi dan bahan-bahan yang diperoleh dari buku, literature, artikel terkait COBIT 4.1, dan IT Governance. Pada tahap pendahuluan ini juga dilakukan studi lapangan untuk meninjau dan mengamati penerapan tata kelola IT pada PT. Metrox Mekanika, mengumpulkan dokumen mengenai visi, misi, struktur organisasi bagian keuangan, serta tugas dan tanggung jawab dari bagian keuangan. Langkah ini dilakukan untuk mendapat pemahaman tentang tata kelola IT pada PT. Metrox Mekanika dan mendapat gambaran peranan bagian keuangan dalam mengelola teknologi informasi pada PT. Metrox Mekanika untuk mendukung organisasi mencapai tujuan bisnisnya.

\section{b. Pemetaan Cobit}

Pada tahap ini dilakukan pemetaan menurut COBIT 4.1 sesuai dengan tujuan bisnis dari PT. Metrox Mekanika. Dimana pada proses pemetaan ini, peneliti mengidentifikasi bisnis goals dan IT goals menurut COBIT 4.1 dan menyesuaikannya dengan tujuan bisnis dari PT. Metrox Mekanika. Dari proses pemetaan ini maka dapat ditemukan domain atau sub-sub domain mana saja yang nantinya dijadikan pedoman dalam penyusunan pertanyaan pertanyaan untuk melakukan proses wawancara.

\section{c. Pengumpulan Data}

Tahap selanjutnya adalah pengumpulan data untuk dapat dilakukan analisis lebih lanjut sehingga dapat menjadi informasi. Metode pengumpulan data yang dilakukan yaitu :

1. Observasi

Observasi dilakukan dengan tujuan untuk mengetahui ciri - ciri dan luasnya obyek yang diamati. Observasi dilakukan pada PT. Metrox Mekanika khususnya bagian keuangan untuk memperoleh data - data dan informasi yang dibutuhkan terkait tata kelola teknologi informasi yang telah diterapkan serta system informasi yang digunakan.

\section{Kuesioner}

Pengisian kuesioner dilakukan dengan 25 responden yaitu 1 Manager Accounting, 1 Manager Keuangan, 2 Cutomer Service Serta 21 staff lainya pada PT. Metrox Mekanika. Tujuan dilakukan pengisian kuesioner ini adalah untuk mengetahui tata Kelola teknologi informasi yang telah dilakukan PT. Metrox Mekanika serta kebijakan-kebijakan yang ditetapkan untuk mengelola teknologi informasi digunakan pada PT. Metrox Mekanika. Pertanyaan pertanyaan dalam kuesioner disusun berdasarkan sub-sub domain Cobit 4.1 yang terindentifikasi dari tujuan bagian keuangan PT. Metrox Mekanika.

\section{Studi Pustaka}

Metode ini dilakukan dengan cara mempelajari buku Cobit 4.1 dan jurnal serta artikel ilmiah sebagai sumber informasi yang relevan, selain itu mempelajari dokumendokumen yang berkaitan dengan tata kelola teknologi informasi pada PT. Metrox Mekanika.

\section{Penentuan Maturity Level.}

Tahap selanjutnya yaitu penentuan Maturity level, yang dimana pada tahap ini peneliti menganalisa hasil kuesioner pada bagian keuangan tentang tata kelola teknologi informasi yang telah diterapkan PT. Metrox Mekanika. Penentuan 
Maturity level ini bertujuan untuk mengetahui sejauh mana tingkat kematangan tata kelola IT yang telah diterapkan (saat ini) oleh PT. Metrox Mekanika apabila diukur dengan Framework Cobit 4.1 serta menentukan tingkat kematangan yang diharapkan. Penentuan Maturity Level ini berdasarkan sub-sub domain yang teridentifikasi dari proses business goals, IT goals menurut Cobit 4.1 serta tujuan dari PT. Metrox Mekanika.

\section{Analisis GAP}

Langkah selanjutnya yaitu menganalisis kesenjangan yang terjadi antara tingkat kematangan saat ini dengan tingkat kematangan yang diharapkan.

6. Rekomendasi

Pada tahap ini peneliti memberikan rekomendasi tekait tata kelola teknologi informasi yang telah dilakukan PT. Metrox Mekanika berdasarkan hasil evaluasi.

\section{Kesimpulan}

Tahap ini peneliti menyimpulkan kinerja dari tata kelola teknologi informasi yang dilakukan bagian keuangan pada PT. Metrox Mekanika berdasarkan hasil dari penelitian.

\section{HASIL PENELITIAN}

Pada tahap ini, menetapkan proses teknologi informasi yang sesuai dengan standar Cobit yang telah diolah sesuai dengan studi kasus. Adapun susunan menurut domainnya, maka proses teknologi informasi di kantor PT. Metrox Mekanika adalah sebagai berikut:

Table IV. 1 Deskripsi Proses Teknologi Informasi

\begin{tabular}{|l|l|}
\hline IT Domain & IT Process \\
\hline Plan and Organise & $\begin{array}{l}\text { PO1, PO2, PO3, PO4, PO5 } \\
P O 6, P O 7, P O 8, P O 9, P O 10\end{array}$ \\
\hline $\begin{array}{l}\text { Acquire and } \\
\text { Implementation }\end{array}$ & $A I 1, A I 2, A I 3, A I 4, A I 5, A I 6, A I 7$ \\
\hline Deliver and Support & $\begin{array}{l}\text { DS1, DS2,DS3, DS4, DS5,DS7, DS8, } \\
D S 10, D S 11, D S 12, D S 13\end{array}$ \\
\hline Monitor and Evaluation & $M E 1, M E 2, M E 3, M E 4$ \\
\hline
\end{tabular}

Analisis dilakukan dengan meninjau dari hasil pemodelan Cobit 4.1 yang telah dilakukan sehingga dapat ditarik kesimpulan. Sebagai salah satu tujuan dalam tulisan ini adalah untuk menemukan bagian mana saja proses yang masih dibawah level 4 dan sudah mencapai level 4 sehingga dapat dilakukan perbaikan dan saran-saran sebagai bahan pertimbangan dengan mengacu pada hasil pemodelan. Bagian domain yang masih kurang dan belum matang akan diteliti lebih rinci. Sehingga penulis menetapkan hanya meneliti pada empat domain $P O, A I, D S$ dan $M E$.

Tabel IV. 2 Evaluasi Proses Teknologi Informasi Pada PT Metrox Mekanika

\begin{tabular}{|l|l|}
\hline IT Domain & IT Process \\
\hline Plan and Organise & PO6.1, PO6.2, PO6.3, PO6.5 \\
\hline Acquire and Implement & $\mathrm{AI} 2.3, \mathrm{AI} 2.4, \mathrm{AI} 2.5, \mathrm{AI} 2.10$ \\
\hline Deliver and Support & $\begin{array}{l}\mathrm{DS} 10.1, \mathrm{DS} 10.2, \quad \mathrm{DS} 10.3, \\
\mathrm{DS} 10.9, \mathrm{DS} 12.2, \mathrm{DS} 12.3, \\
\mathrm{DS} 12.4, \mathrm{DS} 12.5\end{array}$ \\
\hline Monitor and Evaluate & $\mathrm{ME} 1$ \\
\hline $\begin{array}{l}\text { Monitor and Evaluate Internal } \\
\text { Control ME2 }\end{array}$ & \\
\hline
\end{tabular}

Adapun deskripsi tiap-tiap proses teknologi informasi diatas adalah sebagai berikut:

Table IV. 3 Daftar IT Process PT Metrox Mekanika

\begin{tabular}{|l|l|}
\hline Domain & Plan and Organisation \\
\hline PO6 & Communicate management aims and direction \\
\hline Domain & Acquire and Implement \\
\hline AI2 & Acquire and Maintain Application Software \\
\hline Domain & Acquire and Implement \\
\hline DS10 & Manage Problems \\
\hline DS12 & Manage the Physical Environment \\
\hline Domain & Monitor and Evaluation \\
\hline ME1 & Monitor and Evaluate IT Performance \\
\hline ME2 & Monitor and Evaluate Internal Control \\
\hline
\end{tabular}

A. Identifikasi Control Objective

Dari setiap proses teknologi informasi terdapat Detailed Control Objectives yang merupakan alat control dari proses teknologi informasi itu sendiri. Berdasarkan penelitian yang dilakukan terhadap 34 Detailed Control Objectives, sebagai berikut:

Tabel IV. 4 IT Process Control Objective

\begin{tabular}{|c|c|c|}
\hline Domain & $\begin{array}{l}\text { Sub } \\
\text { Domain }\end{array}$ & Description \\
\hline \multirow{4}{*}{$\begin{array}{l}\text { PO6 IT Policy and } \\
\text { Control } \\
\text { Environment }\end{array}$} & $\begin{array}{l}\mathrm{PO} \\
06.01\end{array}$ & IT Policy and Control Environment \\
\hline & $\begin{array}{l}\mathrm{PO} \\
06.02\end{array}$ & $\begin{array}{l}\text { Enterprise IT Risk and Control } \\
\text { Framework }\end{array}$ \\
\hline & $\begin{array}{l}\mathrm{PO} \\
06.03\end{array}$ & IT Policies Management \\
\hline & $\begin{array}{l}\mathrm{PO} \\
06.05\end{array}$ & $\begin{array}{l}\text { Communication of IT Objectives and } \\
\text { Direction }\end{array}$ \\
\hline \multirow{4}{*}{$\begin{array}{l}\mathrm{AI} 2 \text { Acquire and } \\
\text { Implement }\end{array}$} & $\mathrm{AI} 2.3$ & Application Control and Auditability \\
\hline & $\mathrm{AI} 2.4$ & Security and Application Availability \\
\hline & AI2.5 & $\begin{array}{l}\text { Configuration and implement of } \\
\text { Acquired Application Sofware }\end{array}$ \\
\hline & $\mathrm{AI} 2.10$ & Application Software Maintenance \\
\hline \multirow[t]{4}{*}{$\begin{array}{l}\text { DS10 Manage } \\
\text { Problems }\end{array}$} & DS10.1 & $\begin{array}{l}\text { Identification and Classification of } \\
\text { Problems }\end{array}$ \\
\hline & DS10.2 & Problem Tracking and Resolution \\
\hline & DS10.3 & Protection of Security Technology \\
\hline & DS10.4 & $\begin{array}{l}\text { Integration of Configuration, Incident } \\
\text { and Problem Management }\end{array}$ \\
\hline \multirow{3}{*}{$\begin{array}{l}\text { DS12 Manage the } \\
\text { Physical } \\
\text { Environment }\end{array}$} & DS12.2 & Physical Security Measures \\
\hline & DS12.3 & Physical Access \\
\hline & DS12.4 & Protection Against Enviromental Factors \\
\hline
\end{tabular}




\begin{tabular}{|l|l|l|}
\hline & DS12.5 & Physycal Facilities Management \\
\hline ME1 Monitor and & ME1.1 & Monitoring Approach \\
\cline { 2 - 3 } $\begin{array}{l}\text { Evaluate } \\
\text { Performance IT }\end{array}$ & ME1.3 & Monitoring Method \\
\cline { 2 - 4 } & ME1.4 & Performance Assessment \\
\cline { 2 - 3 } & ME1.6 & Remedial Actions \\
\hline ME2 Monitor and \\
$\begin{array}{l}\text { Evaluate Internal } \\
\text { Control }\end{array}$ & ME2.1 & $\begin{array}{l}\text { Monitoring of Internal Control } \\
\text { Framework }\end{array}$ \\
\cline { 2 - 4 } & ME2.2 & Supervisory Review \\
\cline { 2 - 3 } & ME2.3 & \multicolumn{1}{|c|}{ Control Exceptions } \\
\cline { 2 - 3 } & ME2.4 & \multicolumn{2}{|l|}{ Control Self-assessment } \\
\hline
\end{tabular}

\section{B. Menentukan Tingkat Kematangan}

Penentuan tingkat kematangan (maturity level) bukan hanya menggambarkan pengukuran sejauh mana perusahaan telah memenuhi standar proses pengelolaan teknologi informasi yang baik. Lebih jauh lagi, tingkat kedewasaan tersebut seharusnya dapat digunakan untuk peningkatan kesadaran akan kepentingan peningkatan pengelolaan proses teknologi informasi sekaligus pengidentifikasikan prioritas dalam peningkatan yang dilakukan. Tingkat kematangan yang dimaksud merupakan representasi kematangan/kedewasaan proses teknologi informasi yang berlangsung di perusahaan (dalam bentuk nilai/angka).

Adapun penentuan tingkat kematangan akan dilakukan pada tiap proses teknologi informasi dan dilakukan terhadap semua level, mulai dari level 0 (nol) atau non-existence, hingga level 5 (lima) atau optimised, melalui kuisioner dan wawancara langsung perihal pelaksanaan proses teknologi informasi dengan teknologi informasi di kantor PT. Metrox Mekanika. Di dalam sub bab ini penulis menjelasan setiap proses dan level menurut COBIT 4.1, dibandingkan dengan yang ada di perusahaan untuk kemudian diambil kesimpulannya.

Berikut ini adalah indeks kematangan atau maturity level pada COBIT yang digunakan dalam menentukan kondisi tiaptiap domain yang akan diuji:

Table IV. 5 Maturity Level pada COBIT

\begin{tabular}{|l|l|l|}
\hline IndeksKematangan & Level & Keterangan \\
\hline $0-0.49$ & 0 & $0-$ Non-Existent \\
\hline $0.50-1.49$ & 1 & $1-$ Initial/Ad Hoc \\
\hline $1.50-2.49$ & 2 & $2-$ Repeatable But Intutitive \\
\hline $2.50-3.49$ & 3 & $3-$ Defined Process \\
\hline $3.50-4.49$ & 4 & $4-$ Managed and Measureabel \\
\hline-5.00 & 5 & $5 \quad$ Optimized \\
\hline
\end{tabular}

\section{Perhitungan Tingkat Kematangan (Maturity Level)}

Perhitungan tingkat kematangan dihitung berdasarkan hasil kuesioner yang telah diolah, berikut ini adalah detail perhitungan dari masing-masing sub domainnya:

PO6 Communicate Management Aims and Directions (Mengkomunikasikan Tujuan dan Arahan Manajemen)

Table IV. 6 Hasil Perhitungan Evaluasi PO6

\begin{tabular}{|l|l|l|l|l|}
\hline Domain & $\begin{array}{l}\text { Sub } \\
\text { Domain }\end{array}$ & Description & $\begin{array}{l}\text { Current } \\
\text { Maturity }\end{array}$ & Keterangan \\
\hline \multirow{5}{*}{ PO6.1 } & $\begin{array}{l}\text { IT Policy and } \\
\text { Control } \\
\text { Environment }\end{array}$ & 3.96 & $\begin{array}{l}4-\text { Managed } \\
\text { and } \\
\text { Measureabel }\end{array}$ \\
\cline { 2 - 6 } & PO6.2 & $\begin{array}{l}\text { Enterprise IT } \\
\text { Risk } \\
\text { Control and } \\
\text { Framework }\end{array}$ & 4.08 & $\begin{array}{l}4-\text { Managed } \\
\text { and } \\
\text { Measureabel }\end{array}$ \\
\cline { 2 - 6 } & PO6.3 & $\begin{array}{l}\text { IT Policies } \\
\text { Management }\end{array}$ & 4.08 & $\begin{array}{l}4-\text { Managed } \\
\text { and } \\
\text { Measureabel }\end{array}$ \\
\cline { 2 - 6 } & PO6.5 & $\begin{array}{l}\text { Communication } \\
\text { of } \\
\text { Objectives and } \\
\text { Direction }\end{array}$ & 4.00 & $\begin{array}{l}4 \text { Managed } \\
\text { and } \\
\text { Measureabel }\end{array}$ \\
\cline { 2 - 5 } & Rata- Rata & $\begin{array}{l}4 \text { Managed } \\
\text { and } \\
\text { Measureable }\end{array}$ \\
\hline
\end{tabular}

Sumber: Data Penelitian 2021

AI 2 Acquire and Maintain Application Software

Table IV. 7 Hasil Perhitungan Evaluasi AI2

\begin{tabular}{|c|c|c|c|c|}
\hline Domain & $\begin{array}{l}\text { Sub } \\
\text { Domain }\end{array}$ & Description & $\begin{array}{l}\text { Current } \\
\text { Maturity }\end{array}$ & Keterangan \\
\hline \multirow{5}{*}{ AI 2} & $\mathrm{AI} 2.3$ & $\begin{array}{l}\text { Application } \\
\text { Control and } \\
\text { Auditability }\end{array}$ & 4.24 & $\begin{array}{l}4-\text { Managed } \\
\text { and } \\
\text { Measureable }\end{array}$ \\
\hline & $\mathrm{AI} 2.4$ & $\begin{array}{l}\text { Application } \\
\text { Security and } \\
\text { Availability }\end{array}$ & 3.84 & $\begin{array}{l}4-\text { Managed } \\
\text { and } \\
\text { Measureable }\end{array}$ \\
\hline & $\mathrm{AI} 2.5$ & $\begin{array}{l}\text { Configuration } \\
\text { and } \\
\text { implement of } \\
\text { Acquired } \\
\text { Application } \\
\text { Sofware } \\
\end{array}$ & 4.04 & $\begin{array}{l}4-\text { Managed } \\
\text { and } \\
\text { Measureable }\end{array}$ \\
\hline & AI 2.10 & $\begin{array}{l}\text { Development } \\
\text { of Application } \\
\text { Software } \\
\end{array}$ & 4.16 & $\begin{array}{l}4-\text { Managed } \\
\text { and } \\
\text { Measureable }\end{array}$ \\
\hline & \multicolumn{2}{|c|}{ Rata- Rata } & 4.07 & $\begin{array}{l}4-\text { Managed } \\
\text { and } \\
\text { Measureable }\end{array}$ \\
\hline
\end{tabular}

Sumber : Data Penelitian 2021

DS10 Manage Problems 
Table IV. 8 Hasil Perhitungan Evaluasi DS10

\begin{tabular}{|c|c|c|c|c|}
\hline Domain & $\begin{array}{l}\text { Sub } \\
\text { Domain }\end{array}$ & Description & $\begin{array}{l}\text { Current } \\
\text { Maturity }\end{array}$ & Keterangan \\
\hline \multirow{5}{*}{ DS10 } & DS10.1 & $\begin{array}{l}\text { Identification } \\
\text { and } \\
\text { Classification } \\
\text { of Problems }\end{array}$ & 4.08 & $\begin{array}{l}4 \\
\text { Managed } \\
\text { and } \\
\text { Measureable }\end{array}$ \\
\hline & DS10.2 & $\begin{array}{l}\text { Problem } \\
\text { Tracking and } \\
\text { Resolution }\end{array}$ & 3.88 & $\begin{array}{l}4 \\
\text { Managed } \\
\text { and } \\
\text { Measureable }\end{array}$ \\
\hline & DS10.3 & $\begin{array}{l}\text { Protection of } \\
\text { Security } \\
\text { Technology }\end{array}$ & 4.16 & $\begin{array}{l}4 \\
\text { Managed } \\
\text { and } \\
\text { Measureable }\end{array}$ \\
\hline & DS10.4 & $\begin{array}{l}\text { Integration of } \\
\text { Configuration, } \\
\text { Incident and } \\
\text { Problem } \\
\text { Management }\end{array}$ & 4.28 & $\begin{array}{l}4 \\
\text { Managed } \\
\text { and } \\
\text { Measureable }\end{array}$ \\
\hline & \multicolumn{2}{|c|}{ Rata- Rata } & 4.10 & $\begin{array}{l}4 \\
\text { Managed } \\
\text { and } \\
\text { Measureable }\end{array}$ \\
\hline
\end{tabular}

Sumber : Data Penelitian 2021

DS12 Manage the Physical Environment

Table IV. 9 Hasil Perhitungan Evaluasi DS12

\begin{tabular}{|c|c|c|c|c|}
\hline Domain & $\begin{array}{l}\text { Sub } \\
\text { Domain }\end{array}$ & Description & $\begin{array}{l}\text { Current } \\
\text { Maturity }\end{array}$ & Keterangan \\
\hline \multirow{5}{*}{ DS 12} & DS12.2 & $\begin{array}{l}\text { Physical } \\
\text { Security } \\
\text { Measures }\end{array}$ & 4.12 & $\begin{array}{l}4-\text { Managed } \\
\text { and } \\
\text { Measureable }\end{array}$ \\
\hline & DS12.3 & Physical Access & 4.16 & $\begin{array}{l}4-\text { Managed } \\
\text { and } \\
\text { Measureable }\end{array}$ \\
\hline & DS12.4 & $\begin{array}{l}\text { Protection } \\
\text { Against } \\
\text { Enviromental } \\
\text { Factors }\end{array}$ & 4.20 & $\begin{array}{l}4-\text { Managed } \\
\text { and } \\
\text { Measureable }\end{array}$ \\
\hline & DS12.5 & $\begin{array}{l}\text { Physycal } \\
\text { Facilities } \\
\text { Management }\end{array}$ & 4.00 & $\begin{array}{l}4-\text { Managed } \\
\text { and } \\
\text { Measureable }\end{array}$ \\
\hline & \multicolumn{2}{|c|}{ Rata- Rata } & 4.12 & $\begin{array}{l}4-\text { Managed } \\
\text { and } \\
\text { Measureable }\end{array}$ \\
\hline
\end{tabular}

Sumber : Data Penelitian 2021

ME1 Monitor and valuate IT Performance
Table IV. 10 Hasil Perhitungan Evaluasi ME1

\begin{tabular}{|l|l|l|l|l|}
\hline Domain & $\begin{array}{l}\text { Sub } \\
\text { Domain }\end{array}$ & Description & $\begin{array}{l}\text { Current } \\
\text { Maturity }\end{array}$ & Keterangan \\
\hline \multirow{5}{*}{ ME1 } & ME1.1 & $\begin{array}{l}\text { Monitoring } \\
\text { Approach }\end{array}$ & 3.92 & $\begin{array}{l}4-\text { Managed } \\
\text { and } \\
\text { Measureable }\end{array}$ \\
\cline { 2 - 5 } & ME1.3 & $\begin{array}{l}\text { Monitoring } \\
\text { Method }\end{array}$ & 3.96 & $\begin{array}{l}4-\text { Managed } \\
\text { and } \\
\text { Measureable }\end{array}$ \\
\cline { 2 - 5 } & ME1.4 & $\begin{array}{l}\text { Performance } \\
\text { Assessment }\end{array}$ & 4.12 & $\begin{array}{l}4-\text { Managed } \\
\text { and } \\
\text { Measureable }\end{array}$ \\
\cline { 2 - 5 } & Metions & 4.12 & $\begin{array}{l}4-\text { Managed } \\
\text { and } \\
\text { Measureable }\end{array}$ \\
\cline { 2 - 5 } & \multicolumn{2}{|l|}{ Rata-Rata } & 4.03 & $\begin{array}{l}4-\text { Managed } \\
\text { and } \\
\text { Measureable }\end{array}$ \\
\hline
\end{tabular}

Sumber : Data Penelitian 2021

ME2 Monitor and Evaluate Internal Control

Table IV. 10 Hasil Perhitungan Evaluasi ME2

\begin{tabular}{|l|l|l|l|l|}
\hline \multirow{5}{*}{ Domain } & $\begin{array}{l}\text { Sub } \\
\text { Domain }\end{array}$ & Description & $\begin{array}{c}\text { Current } \\
\text { Maturity }\end{array}$ & Keterangan \\
\hline \multirow{5}{*}{ ME2 } & ME2.1 & $\begin{array}{l}\text { Monitoring } \\
\text { Approach }\end{array}$ & 4.08 & $\begin{array}{l}4-\text { Managed } \\
\text { and } \\
\text { Measureable }\end{array}$ \\
\cline { 2 - 5 } & ME2.2 & $\begin{array}{l}\text { Monitoring } \\
\text { Method }\end{array}$ & 3.92 & $\begin{array}{l}4-\text { Managed } \\
\text { and } \\
\text { Measureable }\end{array}$ \\
\cline { 2 - 5 } & Merformance & 4.16 & $\begin{array}{l}4-\text { Managed } \\
\text { and } \\
\text { Measureable }\end{array}$ \\
\cline { 2 - 5 } & ME2.4 & $\begin{array}{l}\text { Remedial } \\
\text { Actions }\end{array}$ & 4.04 & $\begin{array}{l}4-\text { Managed } \\
\text { and } \\
\text { Measureable }\end{array}$ \\
\cline { 2 - 5 } & Rata-Rata & 4.05 & $\begin{array}{l}4-\text { Managed } \\
\text { and } \\
\text { Measureable }\end{array}$ \\
\hline
\end{tabular}

Sumber : Data Penelitian 2021

D. Rangkuman Tingkat Kematangan (Maturity Level)

Rata-rata hasil perhitungan dari domain dijabarkan dalam table dibawah ini:

Table IV. 11 Rata-rata tingkat kematangan domain PO, AI, DS, ME

\begin{tabular}{|l|l|l|ll|}
\hline Domain & Keterangan & Nilai & Keterangan & \\
\hline PO6 & $\begin{array}{l}\text { Communicate } \\
\text { management aims } \\
\text { and direction }\end{array}$ & 4.03 & $\begin{array}{l}4-\text { Managed and } \\
\text { Measureable }\end{array}$ \\
\hline AI 2 & $\begin{array}{l}\text { Acquire and Maintain } \\
\text { Application Software }\end{array}$ & 4.07 & $\begin{array}{l}\text { Managed and } \\
\text { Measureable }\end{array}$ \\
\hline DS10 & Manage Problems & 4.10 & $4-$ Managed and \\
\hline
\end{tabular}




\begin{tabular}{|l|l|l|l|} 
& & & Measureable \\
\hline DS12 & $\begin{array}{l}\text { Manage the Physical } \\
\text { Environment }\end{array}$ & 4.12 & $\begin{array}{l}4-\text { Managed and } \\
\text { Measureable }\end{array}$ \\
\hline ME1 & $\begin{array}{l}\text { Monitor and evaluate } \\
\text { IT performance }\end{array}$ & 4.03 & $\begin{array}{l}4-\text { Managed and } \\
\text { Measureable }\end{array}$ \\
\hline ME2 & $\begin{array}{l}\text { Monitor and Evaluate } \\
\text { Internal Control }\end{array}$ & 4.05 & $\begin{array}{l}4-\text { Managed and } \\
\text { Measureable }\end{array}$ \\
\hline Rata-rata & 4.07 & $\begin{array}{l}4-\text { Managed and } \\
\text { Measureable }\end{array}$ \\
\hline
\end{tabular}

Sumber: Data Penelitian 2021

Hasil perhitungan mendapati rata-rata nilai domain tata kelola teknologi informasi pada PT. Metrox Mekanika sebesar 4.07. Dari nilai ini dapat ditarik kesimpulan bahwa pengelolaan teknologi informasi dilakukan secara Managed and Measurable artinya pada level 4 ini proses standar dalam pengembangan suatu pelayanan telah dikelola dan diukur dengan baik.

\section{E. Nilai Kesenjangan Kematangan Saat Ini}

Berdasarkan rangkuman nilai kematangan diatas dapat diketahui nilai kesenjangan masing-masing domain, yaitu:

Table IV. 12 Hasil Analisis Kesenjangan (Gap)

\begin{tabular}{|l|l|l|l|}
\hline \multirow{2}{*}{ Domain } & \multicolumn{3}{|l|}{ Maturity Level } \\
\cline { 2 - 4 } & $\begin{array}{l}\text { Current } \\
\text { Maturity }\end{array}$ & $\begin{array}{l}\text { Expected } \\
\text { Maturity }\end{array}$ & Gap/ Selisih \\
\hline PO6 & 4.03 & 4 & $(0.03)$ \\
\hline$A I 2$ & 4.07 & 3 & $(1.07)$ \\
\hline$D S 10$ & 4.10 & 4 & $(0.10)$ \\
\hline$D S 12$ & 4.12 & 4 & $(0.12)$ \\
\hline ME1 & 4.03 & 4 & $(0.03)$ \\
\hline ME2 & 4.05 & 4 & $(0.05)$ \\
\hline Rata-rata & & $(0.23)$ \\
\hline
\end{tabular}

Sumber : Data Penelitian 2021

Perbedaan kondisi kesenjangan tata kelola PO, AI, DS, dan ME saat ini dengan tata kelola PO, AI, DS, dan ME yang diharapkan dapat dilihat seperti pada gambar dibawah ini:

\section{Chart Title}
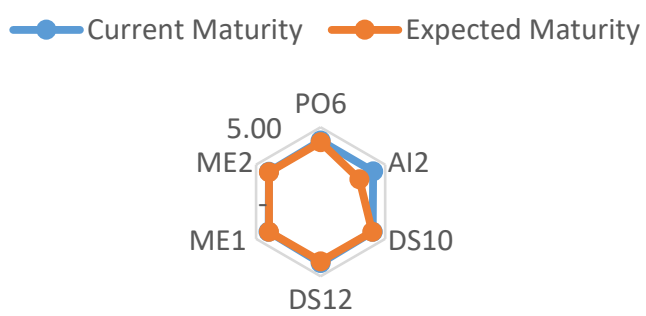

Gambar IV. 1 Perbandingan kesenjangan kondisi tata kelola PO, AI, DS, dan ME saat ini dengan tata kelola yang diharapkan

Sumber : Data Penelitian 2021

\section{F. Hasil Penentuan Temuan Dan Rekomendasi}

Hasil evaluasi menunjukan temuan terdapat gap pada domain PO, DS dan ME, pada domain DS memiliki nilai kesenjangan paling besar yaitu mencapai 0.23. Hal ini menunjukkan masalah yang dihadapi pada pengelolaan teknologi informasi PT. Metrox Mekanika terdapat pada domain DS yaitu DS (Educate and Train Users) yaitu Kurangnya mengidentifikasi kebutuhan bisnis terlebih dahulu dan Kurangnya penggunaan sistem teknologi informasi secara efisien dan efektif, sehingga kebutuhan bisnis belum berjalan stabil dan pengunaan secara efisien dan efektifnya belum diterapkan secara maksimal.

Rekomendasi yang mampu diberikan pada bagian DS adalah perlunya manajemen memberikan penegasan dan tanggung jawab pada masing-masing individu secara jelas maka tiap-tiap orang dapat mempertanggung jawabkan setiap pekerjaannya, sehingga mudah melakukan evaluasi dari setiap bagian yang belum dikerjakan oleh masing masing pihak yang bertanggung jawab. Setiap staf dievaluasi secara berkala untuk memastikan kinerja dapat mendukung bisnis.dievaluasi secara berkala untuk memastikan kinerja dapat mendukung bisnis.

\section{KESIMPULAN DAN SARAN}

\section{A. Kesimpulan}

Berdasarkan hasil penelitian yang telah dilakukan maka dapat ditarik kesimpulan sebagai berikut:

1. PT. Metrox Mekanika telah menerapkan tata kelola teknologi informasi pada level Defined Process. Hasil pengolahan kuisioner mendapati nilai rata-rata untuk domain PO, AI, DS dan ME adalah 4.07 dari rentang nilai 0 sampai 5. Artinya perusahaan telah melakukan tata kelola teknologi informasi dengan baik.

2. Hasil penelitian menemukan kelemahan terdapat pada subdomain PO6 dan ME1, dimana memiliki nilai kematangan paling kecil yaitu 4.03 yang dimana belum adanya pengukuran seberapa mudah dan sulitnya dalam mengoperasikan ERP juga perlu adanya evaluasi tingkat kematangan penerapan ERP pada PT. Metrox Metanika.

\section{B. Saran}

1. Langkah pertama yang harus dilakukan oleh perusahaan dalam memperbaiki tata kelola TI-nya adalah meningkatkan tata kelola pada subdomain ME1.3 melakukan pengawasan dan penilaian terhadap kinerja TI serta memastikan apakah implementasi dari kinerja TI tersebut sudah berjalan secara efektif. Dalam melakukan pengawasan dan penilaian, organisasi haruslah menetapkan suatu indikator atau ukuran kinerja yang dapat dijadikan sebagai acuan dalam menentukan keberhasilan target yang diharapkan secara rutin, sehingga saran perbaikan yang diberikan adalah menetapkan standar prosedur dalam monitoring dan penilaian yang berisi mekanisme tata cara dalam melakukan pengawasan yang 
disesuaikan dengan karakteristik teknologi informasi dari instansi, membuat hasil laporan dari kegiatan pengawasan dan penilaian yang telah dilakukan dengan menggunakan indikator kinerja yang telah ditentukan dan menyampaikannya kepada pemangku kepentingan yang terlibat, membuat perencanaan dan menetapkan jadwal untuk melakukan pengawasan dan penilaian secara rutin yang disesuaikan dengan standar prosedur yang telah disepakati sesuai rekomendasi yang telah diberikan oleh penulis.

2. Dan pada sub domain PO6 berfokus terhadap pengelolaan tujuan dan arahan TI agar sesuai dengan tujuan bisnis organisasi atau perusahaan diikuti dengan adanya komunikasi yang dilakukan manajemen terhadap jajaran personel dalam suatu organisasi atau perusahaan tentang visi, misi, kebijakan, maupun standar prosedur, sehingga rekomendasi yang diberikan adalah manajemen harus melakukan pembahasan mengenai pentingnya kesadaran akan keamanan teknologi infomasi.

3. Mempersiapkan SDM untuk menyusun metode pemantauan sehingga ada tolak ukur yang konsisten dalam proses pemantauan sehingga permasalahan yang ditemukan dapat diminimalisir dan cepat diatasi.

\section{DAFTAR PUSTAKA}

[1] R. I. Elisabet Yunaeti Anggraini, Pengantar Sistem Informasi. Yogyakarta: CV. Andi Offset, 2017.

[2] L. Hakim, Prinsip-Prinsip Dasar Sistem Informasi Manajemen: Dilengkapi Teori Dasar Sistem Informasi Manajemen Pendidikan, no. i. 2019.

[3] Janner Simarmata Dkk, Pengantar Manajemen Sistem Informasi. Yayasan Kita Menulis, 2020.

[4] Syafnidawaty, "TEKNOLOGI INFORMASI," raharja.ac.id, 2020. https://raharja.ac.id/2020/11/21/teknologiinformasi/.

[5] K. Kurniawan, "Pengertian Informasi," projasaweb.com, 2021. https://projasaweb.com/pengertian-informasi/.

[6] M. T. I Putu Agus Swastika, M.Kom., I Gusti Lanang Agung Raditya Putra, S.Pd., Audit Sistem Informasi dan Tata Kelola Teknologi Informasi. Yogyakarta: CV. Andi Offset, 2016.

[7] D. Soelistya and H. A. Agustina, "ANALISIS TEKNOLOGI INFORMASI MOBILE BANKING DAN PERSEPSI RISIKO TRANSAKSI TERHADAP KEPUASAN NASABAH (Studi Kasus Bank Mandiri Syariah Cabang Jemur Handayani Surabaya)," Account. Manag. J., vol. 1, no. 2, pp. 89-100, 2018, doi: 10.33086/amj.v1i2.77.

[8] N. PER-01/PJ/2017, "PENERAPAN TEKNOLOGI INFORMASI DALAM PENINGKATAN EFEKTIVITAS, EFISIENSI DAN PRODUKTIVITAS PERUSAHAAN," Occup. Med. (Chic. Ill)., vol. 53, no. 4, p. 130, 2017.

[9] Ni Luh Putu Giri Gita Saraswati, "Enterprise Resource Planning," 2018. https://girigitasaraswati.wordpress.com/2018/09/09/modul-modulpada-enterprise-resource-planning/.

[10] Muhammad Robith Adani, "Pengenalan Apa Itu Framework dan Jenisnya untuk Web Development," 2020. https://www.sekawanmedia.co.id/pengertian-framework/.
[11] Amera P. Safira, "Apa Itu Framework? Pengertian, Manfaat, \& Jenisnya,” 2021. https://www.goldenfast.net/blog/apaitu-framework/.

[12] C. B. Eva Zuraidah, Audit Sistem Informasi dan Manajemen Menggunakan Cobit 4 dan 5, Cetakan I. Yogyakarta: Graha Imu, 2021.

[13] Winalia1, F. Renaldi, and A. I. Hadiana, "Pengukuran Tingkat Kematangan Teknologi Informasi Menggunakan Cobit 4.1 Pada Universitas Jenderal Achmad Yani,” Semin. Nas. Apl. Teknol. Inf., no. 1907-5022, pp. 31-36, 2017.

[14] I. G. Institute, Ch4.1 - Cobit 4.1. 2007.

[15] D. Nana and H. Elin, "Memilih Metode Penelitian Yang Tepat: Bagi Penelitian Bidang Ilmu Manajemen," J. Ilmu Manaj., vol. 5, no. 1, p. 288, 2018, [Online]. Available: https://jurnal.unigal.ac.id/index.php/ekonologi/article/view/1359.

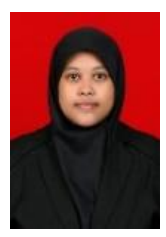

Erma Zulhijjah,Jakarta 19 Juli 1989. Sarjana Komputer Universitas Nusa Mandiri, Karyawan Swasta di Lembaga Filantropi.

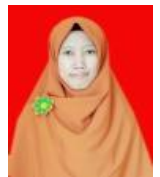

Nur Lutfiyana, Jakarrta, 29 Maret 1987,S2 Universitas Nusa Mandiri, Dosen di beberapa kampus swasta. Buku yang pernah dipublikasikan Decision Support System (DSS). 